\author{
JERZY DYGDAEA \\ Instytut Historii PAN, Toruń
}

\title{
DZIEJE FRYDERYCJAŃSKICH PRUS W XVIII W., CZYLI O WYŻSZOŚCI ABSOLUTYZMU NAD SZLACHECKĄ WOLNOŚCIĄ*
}

Jednym z najważniejszych zadań postawionych przed polską nauką historyczną po II wojnie światowej przez ówczesnych decydentów było przygotowanie nowych syntez historii Polski i obszarów włączonych wówczas w skład państwa polskiego - Pomorza i Śląska. Miały one być pisane na podstawie nowej, marksistowskiej metodologii i powinny były udowadniać odwieczne związki tych terenów z dawną, piastowską Polską. Ciasny gorset ideologiczny wkrótce jednak został znacznie rozluźniony i nowa, wielotomowa synteza Historia Polski (wydawana przez Instytut Historii PAN pod red. Tadeusza Manteuffla), kładąc wprawdzie nacisk na sprawy społeczne i gospodarcze (ujmowane niekiedy monograficznie), bynajmniej nie zaniedbała dziejów politycznych i kultury. Także przygotowywane od lat pięćdziesiątych syntezy dziejów śląska i Pomorza (ta ostatnia bynajmniej jeszcze nie zakończona) stały na dobrym poziomie naukowym i przejawiały na ogół obiektywizm w przedstawianiu skomplikowanych pod względem narodowościowym losów tych terytoriów. Cechą charakterystyczną prac nad tymi syntezami było częste sięganie bezpośrednio do materiałów źródłowych. Wynikało to nieraz z faktu braku podstawowych ujęć monograficznych niektórych aspektów przeszłości. Autorzy syntez musieli więc wypełniać istotne luki badawcze, co prowadziło do znaczącego przekraczania terminów publikacji poszczególnych tomów, a syntezy stawały się swego rodzaju zbiorami studiów monograficznych.

W latach osiemdziesiątych XX w.w środowisku historyków poznańskich rozpoczęto prace nad pełną polską historią państwa brandenbursko-pruskiego, która miała niejako uzupełniać syntezy dziejów Pomorza i śląska, prowincji przez

* Na marginesie: Prusy w okresie monarchii absolutnej (1701-1806), red. Bogdan Wachowiak, Poznań 2010, Wydawnictwo Poznańskie, ss. 1015, Historia Prus. Narodziny Mocarstwowość - Obumieranie, 2. 
długi czas wchodzących w skład tegoż państwa. Ta nowa praca, pod względem metodologicznym (i konstrukcyjnym) miała nawiązywać do wypracowanych już w polskiej nauce historycznej zasad tworzenia wielkich, często drobiazgowych syntez. Pierwszy tom Historii Prus pod tytułem Dzieje Brandenburgii-Prus na progu czasów nowożytnych (1500-1701) został opublikowany w 2001 r.

Obecnie wydany tom drugi Historii Prus obejmuje okres od 1701 r., koronacji elektora Fryderyka III na króla w Prusach, do całkowitej klęski państwa pruskiego w 1806 r. podczas wojny z napoleońską Francją, co wymusiło następnie przeprowadzenie zasadniczych reform ustrojowych i społecznych. Okres ten słusznie został określony jako czasy monarchii absolutnej. Ta bardzo obszerna i szczegółowa książka jest dziełem pięciu autorów. Blisko połowę tekstu (42,6\%) napisał Zygmunt Szultka (rozdziały poświęcone stosunkom gospodarczym, społecznym i ustrojowym). Autorem jednej czwartej (24,7\%) pracy jest Andrzej Kamieński, który omówił politykę zagraniczną Prus w latach 1701-1786 oraz problemy rozwoju architektury. Dariusz Łukasiewicz poświęcił prawie 15\% tekstu książki na przedstawienie spraw szeroko pojętej kultury (jest też autorem małego podrozdziału o przejęciu Prus Królewskich przez administrację pruską). Grzegorz Kucharczyk (10,3\% tekstu) zajął się przełomem XVIII/XIX w. (polityką zagraniczną i przejawami kryzysu wewnętrznego podczas panowania Fryderyka Wilhelma II i Fryderyka Wilhelma III oraz ruchem wydawniczym w całym XVIII stuleciu). Bogdan Wachowiak jest redaktorem całego tomu, autorem wprowadzenia, szczegółowego omówienia źródeł i literatury oraz obszernego podsumowania (razem 7,5\% całej książki). Pewnego rodzaju przesunięcie w stronę spraw ustrojowo-gospodarczych nie powinno razić, gdyż w przypadku Prus to właśnie one decydowały o politycznych i militarnych możliwościach tego państwa.

Charakterystyczną cechą pracy jest niezwykle skrupulatne wykorzystanie praktycznie całej dotychczasowej literatury, przede wszystkim niemieckiej, ale także anglojęzycznej, francuskiej i oczywiście polskiej. Autorzy nieraz przeprowadzali też dodatkowe kwerendy archiwalne (zwłaszcza dotyczy to rozdziałów napisanych przez Z. Szultkę). Dlatego też pod względem faktograficznym jest to nie tyle synteza, ile raczej kompendium wiedzy o państwie pruskim XVIII i początków XIX w. (nie jest to bynajmniej zarzut!). Otrzymaliśmy bowiem zbiór studiów, niekiedy wręcz monograficznych, przynoszących wiele bardzo szczegółowych i cennych informacji, odpowiednio uporządkowanych, przy czym Autorzy dają też wnikliwe komentarze i analizę przebiegu procesu dziejowego. Moim zdaniem przypisy są tu jednak zbyt rozbudowane (jak na syntezę), wystarczyło chyba powoływać się na nowsze opracowania, gdzie cytuje się dawniejszą literaturę. Wobec tak szczegółowych przypisów nie bardzo zresztą widzę potrzebę umieszczenia w tej pracy osobnego rozdziału zawierającego charakterystykę źródeł i literatury.

Zakres terytorialny pracy nie ogranicza się tylko do Brandenburgii, Pomorza Zachodniego i Prus Książęcych - a w polskiej historiografii na ogół tak właśnie pojmuje się państwo pruskie. Uwzględniono tu również, znacznie słabiej u nas znane, centralne i zachodnie (nadreńskie) prowincje Prus. 
Struktura wewnętrzna pracy wydaje się przejrzysta.Zasadniczy podział książki na trzy okresy (części) ujęte chronologiczne (1701-1740,1740-1786, 1786-1806) uznać należy za niewątpliwie trafny. Wewnętrzna konstrukcja tych części jest już jednak zagmatwana i nieprzejrzysta, by nie powiedzieć chaotyczna. Niezbyt pojmuję, czemu w części trzeciej dotyczącej okresu 1786-1806 znalazły się dwa rozdziały omawiające sprawy wyznaniowe oraz kultury dla całego XVIII stulecia. Albo należało umieścić je w odrębnej, czwartej części, albo - co moim zdaniem byłoby właściwsze - podzielić je na mniejsze podokresy i wprowadzić do poszczególnych chronologicznych części tej syntezy.

Jeżeli kładzie się nacisk na absolutystyczny charakter państwa pruskiego w XVIII w., to nie można panujących tam władców traktować jako drugorzędny czynnik zasadniczych wydarzeń historycznych i zjawisk społecznych. Dlatego też zupełnie nie rozumiem, czemu ogólna charakterystyka tak wybitnej i wyrazistej postaci Fryderyka Wielkiego, jego osobowości i jego poglądów społeczno-politycznych znalazła się dopiero na s. 571-579 jako trzeci podrozdział rozdziału szóstego pt. „Stosunki ustrojowe i społeczne w państwie Fryderyka II”. Podrozdział ten, odpowiednio poszerzony (choćby o analizę jego konfliktu z ojcem, o zainteresowania intelektualne i artystyczne króla, jego zdolności militarne), bezwarunkowo powinien otwierać drugą część syntezy, a więc od tego powinno się zacząć omawianie dziejów Prus w okresie rządów tego monarchy. Inna rzecz, że tenże rozdział szósty powinien znajdować się na początku drugiej części syntezy poświęconej okresowi panowania tego władcy - podobnie jak to było w części pierwszej dotyczącej rządów Fryderyka I i Fryderyka Wilhelma I. Tak samo zresztą w pierwszym rozdziale części trzeciej G. Kucharczyk zaczyna narrację dotyczącą polityki zagranicznej Prus w czasach Fryderyka Wilhelma II od planu zamiennego ministra Ewalda Friedricha Hertzberga, w ogóle nie informując o nowym władcy, jego wykształceniu i kompetencjach, koncepcjach politycznych, zainteresowaniach itp. Nie mam wątpliwości, że wszystkie trzy zasadnicze części tej syntezy powinny zaczynać się od przedstawienia sylwetek kolejnych królów pruskich!

Z. Szultka rozpoczyna zresztą swój wykład od koronacji Fryderyka I na króla w Prusach, ukazując szeroki europejski kontekst tego wydarzenia, nie wynikało ono bowiem tylko z nadmiernych ambicji elektora brandenburskiego, ale też z obaw, że wobec uzyskania koron królewskich przez innych elektorów (saskiego i hanowerskiego, którzy mieli panować w Rzeczypospolitej i Wielkiej Brytanii) pozycja Prus w Rzeszy ulegnie osłabieniu. Autor szybko przechodzi jednak do charakterystyki rządów Fryderyka Wilhelma I i jego graniczącej ze skąpstwem oszczędności, związanej z przeznaczaniem większości dochodów na zwiększenie liczby wojska. Przy okazji zwraca uwagę na miejsce stanów w krajach wchodzących w skład państwa pruskiego. W drugiej połowie XVII i w początkach XVIII w. nie doszło wprawdzie do formalnej likwidacji instytucji stanowych samorządów, ale - w związku z wprowadzeniem stałych podatków - stopniowo zamierała ich działalność, ograniczając się co najwyżej do mniej ważnych spraw lokalnych. Instytucje te poddane były zresztą coraz ściślejszej kontroli ze strony królewskiej 
biurokracji. Zupełny brak współdziałania między stanami poszczególnych krajów ułatwiał administracji centralnej ograniczenie ich roli.

Według Z. Szultki większość społeczeństwa krajów pruskich miała zdecydowanie negatywny stosunek do polityki wewnętrznej Fryderyka Wilhelma I. Wynikało to z nadmiernej i kosztownej militaryzacji państwa, obaw przed wcieleniem do wojska i surową dyscypliną (dotyczyło to chłopów i mieszczan), niechęci szlachty do werbunków pozbawiających ją poddanych. Jednak z drugiej strony istniały coraz większe możliwości uzyskania stanowisk oficerskich dla synów szlacheckich. Dopiero wprowadzenie systemu kantonalnego w 1733 r. oznaczało przejęcie faktycznej kontroli państwa nad ludnością chłopską i zmniejszenie jej zależności od szlachty. Uciążliwości dożywotniej służby wojskowej łagodził zresztą wprowadzony wówczas system corocznych, dziewięciomiesięcznych urlopów, udzielanych rekrutom po odbyciu podstawowego przeszkolenia wojskowego.

Z. Szultka szczegółowo omówił też politykę demograficzną i ekonomiczną Fryderyka Wielkiego.Zwrócił uwagę na rolę kolonizacji fryderycjańskiej (280-350 tys. osadników) w zwiększeniu liczby ludności (wydano na ten cel jednak aż $50 \mathrm{mln}$ talarów), szeroko zakrojone prace melioracyjne i zagospodarowywanie nieużytków, troskę o stan sanitarny kraju (spadek śmiertelności), zapobieganie klęskom głodu (magazynowanie nadwyżek zboża). Interesująca jest analiza polityki gospodarczej Fryderyka II, zwłaszcza po wojnie siedmioletniej i wywołanym przez nią ogólnoeuropejskim kryzysie finansowym. Autorytaryzm króla, nierozumiejącego istoty kryzysu, wpływał na podejmowanie błędnych decyzji w duchu ekstremalnego jak to słusznie określił Z. Szultka - merkantylizmu. Podwyższenie wartości pieniądza przyniosło deflację, a zakaz importu towarów zagranicznych uderzył w kupiectwo. Doszła do tego protekcyjna polityka wobec produkcji manufakturowej, niezależnie od jej opłacalności, co dotyczyło zwłaszcza jedwabnictwa rozwijanego mimo niesprzyjających warunków klimatycznych. Skończyło się spektakularnym bankructwem największego przedsiębiorcy pruskiego Johanna Gotzkowskiego. Winą za trudności gospodarcze król obarczał kupiectwo (zwłaszcza berlińskie), rzekomo wywożące kapitały za granicę ${ }^{1}$. Próby zwrócenia monarsze uwagi na możliwość korekty tej polityki i wprowadzenie elementów fizjokratyzmu (m.in. wolności handlu) nie przyniosły żadnych efektów, a osoby to doradzające mogły się liczyć z dymisją, a nawet uwięzieniem. Ożywienie gospodarcze z lat siedemdziesiątych XVIII w. utwierdziło zresztą Fryderyka Wielkiego w przekonaniu o skuteczności swej polityki i przytłumiło głosy krytyczne. Szczególne znaczenie miały wówczas inwestycje państwowo-prywatne w przemysł górniczy i hutniczy na

${ }^{1}$ Zdecydowanie negatywnie oceniał ówczesną politykę gospodarczą Fryderyka II jako niekorzystną dla handlu i kupiectwa pochodzący z Saksonii członek polskiej Komisji Skarbu Nadwornego Jan Steinhauser, mający długoletnią praktykę w sprawach finansowych, por. J. Dygdała, Fryderycjańskie Prusy w świetle listów sasko-polskiego urzędnika skarbowego Jana Beniamina Steinhausera z lat sześćdziesiatych XVIII wieku, w: Nad Battykiem, Pregoła i Łyna XVI-XX wiek. Księga Pamiatkowa poświęcona Jubileuszowi 50-lecia pracy naukowej Profesora Janusza Jasińskiego, red. Z. Rondomańska, Olsztyn 2006, s. 213-216. 
Górnym Śląsku. Pewnym zaskoczeniem dla czytelnika jest stwierdzenie, że do końca XVIII w. głównym towarem eksportowym Prus (przynoszącym też największe dochody) było płótno lniane, produkowane przede wszystkim na Śląsku.

Szczególnie interesujący jest podrozdział „Wieś i rolnictwo w dobie Fryderyka II". W jakiejś mierze była to kontynuacja polityki rolnej jego ojca Fryderyka Wilhelma I, ale znacznie wyraźniej akcentowano istotną rolę państwa w rozwoju rolnictwa. Fryderyk Wielki kładł nacisk przede wszystkim na ogólne poszerzenie areału ziem uprawnych (melioracje), a także na intensyfikację produkcji rolnej w domenach królewskich (m.in. płodozmian, uprawa ziemniaków i roślin motylkowych). Powstawanie ziemstw kredytowych stosunkowo łatwo udzielających szlacheckim właścicielom ziemskim pożyczek inwestycyjnych przyczyniło się do unowocześnienia majątków zamożnej szlachty (ale także do spekulacyjnego wzrostu cen ziemi). Przykładanie tak dużej wagi do rolnictwa wynikało z konieczności wyżywienia szybko zwiększającej się liczby ludności.

W rozdziale szóstym Z. Szultka przedstawił problematykę ustrojową i społeczną państwa pruskiego w dobie panowania Fryderyka Wielkiego. Zwrócił uwagę na stopniowe tworzenie w administracji departamentów (ministerstw) resortowych, co nie oznaczało jednak zerwania z systemem centralnych organów zajmujących się poszczególnymi prowincjami państwa pruskiego. Nieco chaotyczne reorganizacje administracji w okresie przed wojną siedmioletnią wynikały, zdaniem Autora, z odchodzenia od kolegialności organów władzy i wzmacniania pozycji absolutystycznego władcy jako „pierwszego sługi” państwa. Najważniejszą instytucją stał się królewski gabinet, a wobec większości swych ministrów Fryderyk II przejawiał czasem daleko posuniętą nieufność, mieli oni jedynie wykonywać polecenia władcy. System gabinetowych rządów osobistych jeszcze bardziej się wzmocnił po 1763 r., zwłaszcza sprawy polityki zagranicznej pozostawały w wyłącznej dyspozycji króla. Inteligencja i pracowitość Fryderyka Wielkiego sprawiła, że system ten działał stosunkowo skutecznie, choć jak słusznie twierdzi Z. Szultka, ,taki system miał więcej wad niż zalet i prowadził do nieuniknionego kryzysu państwa" (s. 558).

Odrębny podrozdział poświęcono reformom prawa i sądownictwa. Fryderykowi Wielkiemu, dobrze znającemu nowe, oświeceniowe teorie prawa, zależało przede wszystkim na przyśpieszeniu procesu wymierzania sprawiedliwości, dlatego też rozpoczął głęboką reorganizację sądownictwa i jego unifikację. Sprzeciwiał się natomiast postulatom pełnej niezawisłości sądów, gdyż oznaczałoby to ograniczenie jego kompetencji jako władcy absolutnego. Zachowując prawo zatwierdzania wyroków, działał jednak w duchu humanitaryzmu (m.in. w 1754 r. zniósł stosowanie tortur); praktyka ta, wpływając na postępowanie sądów, niejako zastępowała niedoszłą kodyfikację, o której też zresztą myślano. Królewska ingerencja w wymiar sprawiedliwości przynosiła czasem negatywne skutki, co najlepiej odzwierciedla przedstawiona w książce (s. 568) słynna sprawa młynarza Arnolda. Po przegraniu procesu o zapłatę czynszu odwołał się on do Fryderyka II, który bezpodstawnie uznał, iż to młynarz miał rację, i surowo ukarał sędziów prowadzących tę sprawę. Królowi decyzja ta 
przyniosła (niezasłużoną) sławę obrońcy poddanych i promotora równości wszystkich wobec prawa. Z. Szultka zwraca przy tym uwagę, że ewidentne złagodzenie polityki karnej nie obejmowało armii, w której utrzymano bardzo surowe kary za niesubordynację, a zwłaszcza za dezercję. Autor, charakteryzując poglądy społeczno-polityczne Fryderyka Wielkiego, stwierdza, iż wywodził on swą dziedziczną władzę absolutną już nie z woli Bożej (jak to czynił jeszcze jego ojciec), ale z odpowiednio interpretowanej, oświeceniowej teorii umowy społecznej; to wolni i równi ludzie przekazali, raz na zawsze, władzę osobie wybranej spośród siebie. Monarchowie zaś, będąc ludźmi, są równi innym, nie mogą więc, podobnie jak ich poddani, uchylać się od spełniania swych powinności. Skąd też brało się u króla przekonanie, iż jest pierwszym sługą państwa.

Z. Szultka próbuje też odpowiedzieć na pytanie, w jakim stopniu Prusy fryderycjańskie były absolutną monarchią oświeceniową. Zauważa, że Fryderyk Wielki przejmował w sposób mocno wybiórczy idee oświecenia, przede wszystkim te, które pozwalały wzmacniać i modernizować państwo, nie naruszając jednak systemu osobistej władzy absolutnej, sprawowanej w interesie tegoż państwa. Zgadza się też z większością badaczy doceniających rolę inspiracji oświeceniowych w dziele reform wymiaru sprawiedliwości, wprowadzaniu tolerancji religijnej i powszechnego szkolnictwa, podkreśla jednak przy tym, że decydujące znaczenie dla króla miała racja stanu państwa pruskiego.

Niezbyt pojmuję, czemu dopiero po tym podrozdziale, niejako podsumowującym efekty działań Fryderyka Wielkiego, umieszczono podrozdział poświęcony finansom i polityce finansowej tegoż władcy. Z. Szultka przedstawił tu zasady tej polityki podporządkowanej powiększeniu liczebności armii i gromadzeniu odpowiednich zasobów pieniężnych na potrzeby przyszłych wojen. Omówił też reformy monetarne (dewaluację z 1750 r. i następne z czasów wojny siedmioletniej połączone $\mathrm{z}$ fałszowaniem pieniądza, a następnie przywrócenie wartości dawnej monety, co wiązało się z deflacją). Jeżeli początkowo król zwiększał dochody państwa głównie dzięki podatkom pośrednim (akcyza), to po 1763 r. coraz częściej wprowadzał monopole (tytoniowy, kawowy, solny), a także, idąc za wzorami francuskimi, znacząco zwiększył podatki pośrednie, wydzierżawione specjalnej administracji (Regie). Spotkało się to z ogromnym niezadowoleniem wszystkich warstw społecznych, ale przyniosło nadwyżkę dochodów w wysokości co najmniej 24 mln talarów. Z. Szultka podkreśla, że próby oszacowania rzeczywistego bilansu skarbowości pruskiej w czasach Fryderyka II nastręczają bardzo poważne trudności, wynikające z nakładania się na siebie kompetencji poszczególnych instytucji finansowych i świadomych działań króla, który utrzymywał stan finansów państwa w głębokiej tajemnicy, tak że nawet jego ministrowie nie mieli w tej kwestii wystarczającej wiedzy. Praktycznie przez cały czas panowania Fryderyka II dysponował on sporymi rezerwami finansowymi (nawet $\mathrm{w}$ dobie wojen śląskich i wojny siedmioletniej), co, jak wskazuje Autor, korzystnie odróżniało Prusy od większości państw europejskich.

Nie jest dla mnie jasne, dlaczego znalazły się w tym rozdziale dwa, skądinąd cenne, ostatnie podrozdziały poświęcone obszernej (może nawet zbyt obszernej) 
analizie funkcji szlachty w pruskim systemie państwowym i militarnym oraz omówieniu przeprowadzanych i zamierzonych reform stosunków społecznych na wsi. Kwestie te były przecież już w kilku miejscach sygnalizowane wcześniej. Moim zdaniem sprawy te mogłyby być szerzej poruszone w rozdziale czwartym, dotyczącym terytorium i ludności państwa pruskiego w czasach Fryderyka Wielkiego.

Z. Szultka jest też autorem rozdziału w części trzeciej dotyczącego stosunków społeczno-gospodarczych w miastach i na obszarach wiejskich w latach 17861806. Rozpoczyna od wpływu wydarzeń międzynarodowych na życie gospodarcze Prus, podkreślając, że u schyłku swego życia schorowany Fryderyk Wielki nie był w stanie kierować polityką gospodarczą państwa ani sprawować skutecznej kontroli nad sprawami wewnętrznymi. Rządy Fryderyka Wilhelma II i następujący w ich wyniku upadek dyscypliny finansowej doprowadziły budżet państwa do deficytu (była to jedna z przyczyn wycofania się Prus w 1795 r. z wojny z Francją). Środki zaradcze podejmowane w dobie panowania Fryderyka Wilhelma III pozwoliły wprawdzie na wypracowanie nadwyżek, ale pożyczki zaciągnięte na wojnę z Napoleonem w 1806 r. znacząco zwiększyły zadłużenie państwa. Paradoksalnie, do zwiększenia skali trudności finansowych przyczynił się gwałtowny wzrost cen na produkty rolne i masowy eksport zboża, którego zaczęło brakować na rynku wewnętrznym. Podrozdział poświęcony społeczno-ekonomicznym aspektom pruskiej administracji w zagarniętych prowincjach polskich w pewnej mierze nakłada się na umieszczony wcześniej podobny podrozdział pióra G. Kucharczyka (choć tekst Z. Szultki jest bardziej szczegółowy). Obaj autorzy negatywnie oceniają efekty rządów pruskich na tych terenach. Odrębne miejsce zajmuje w tym rozdziale sprawa stopniowego uwłaszczania chłopów w domenach państwowych na przełomie XVIII/XIX w. Z. Szultka, przeprowadzając krótki bilans polityki gospodarczej i społecznej Prus tego okresu, docenia wprawdzie osiągnięcia z doby Fryderyka Wielkiego (rządzono „racjonalnie, choć apodyktycznie”), uważa jednak, iż uzyskano to „przestarzałymi metodami i bez aktywnego współuczestnictwa społeczeństwa” (s. 744), które później nie było zdolne do samodzielnego działania (zwłaszcza że następni władcy okazali się już znacznie mniej utalentowani).

A. Kamieński zajął się polityką zagraniczną Prus w latach 1701-1786. Rozdziały te charakteryzuje płynna i interesująca narracja oraz umiejętne przedstawienie skomplikowanej gry dyplomatycznej i działań militarnych (zwłaszcza dotyczy to epoki Fryderyka Wielkiego). Omawiając politykę pruską do 1740 r., Autor położył nacisk na rozbudowę armii i na ostrożność w stosunkach z sąsiadami. Największym sukcesem było oczywiście uzyskanie, w wyniku wojny północnej z początku XVIII w., tzw. Pomorza Przedniego ze Szczecinem. Zbędny wydaje mi się w tym miejscu podrozdział o polityce Fryderyka I i Fryderyka Wilhelma I wobec Polski. Mimo wszystko nie był to wówczas zasadniczy wątek pruskiej polityki ${ }^{2}$,

${ }^{2}$ Warto jednak zauważyć, że są badacze, którzy bardzo wyraźnie akcentują znaczenie polityki Prus wobec Rzeczypospolitej dla wyniesienia swego państwa do roli mocarstwa zob. m.in. K. Zernack, Negatywna polityka wobec sprawy polskiej jako podstawa 
istotne sprawy związane ze stosunkiem Prus do Rzeczypospolitej zostały zresztą poruszone już w innych podrozdziałach, stąd też pojawiło się w tekście sporo powtórzeń. Osobiście wprowadziłbym w tym rozdziale narrację chronologiczną (zabiegi o koronę, udział Prus w wojnie o sukcesję hiszpańską, zajęcie Pomorza Szczecińskiego, Prusy między Rosją, Austrią i Francją, postawa wobec polskiej elekcji z 1733 r., antyhabsburski związek z Francją).

Bardzo dobre wrażenie robi na czytelniku rozdział „Polityka zagraniczna i wojny Fryderyka II w latach 1740-1763”, poświęcony przede wszystkim konfliktowi z Austrią o Śląsk i przebiegowi wojen śląskich oraz wojny siedmioletniej. Charakteryzuje się on żywą narracją i logicznym powiązaniem poszczególnych faktów. Mam natomiast wątpliwości, czy warto było wyodrębnić sprawy polskie (w tym pierwszy rozbiór) w następnym rozdziale. Kwestie te dla lat 1740-1763 zostały bowiem już zasygnalizowane $\mathrm{w}$ rozdziale poprzednim, a problematyka stosunku Fryderyka II do reform stanisławowskich i jego udziału w pierwszym rozbiorze Rzeczypospolitej mogła zostać ujęta bardziej skrótowo i stanowić jedynie podrozdział w większym rozdziale dotyczącym polityki zagranicznej Prus. Trzeba przy tym pamiętać, że Autor, pisząc ten rozdział, nie miał dostępu do archiwaliów rosyjskich, a dopiero ich wykorzystanie (wystarczy tu wskazać na najnowsze publikacje Zofii Zielińskiej i jej uczniów Urszuli Kosińskiej i Jacka Nowickiego) sprawia, że możemy wysuwać bardziej udokumentowane twierdzenia o rzeczywistym wpływie wzajemnych stosunków rosyjsko-pruskich na sprawy polskie. Wydaje mi się, że źródła pruskie dają tu obraz zbyt jednostronny. Tym bardziej zalecana więc byłaby skrótowość i syntetyczne ujęcie tej problematyki. Przyjęcie w kolejnym rozdziale poświęconym polityce pruskiej w latach 1772-1786 układu terytorialnego (osobno stosunki z Rosją, Austrią, księstwami Rzeszy, Polską) pociąga za sobą liczne powtórzenia i jedynie komplikuje wyjaśnianie meandrów pruskiej polityki. Znacznie lepsza byłaby, moim zdaniem, prosta narracja chronologiczna pokazująca coraz większe osamotnienie Prus i narastające obawy Fryderyka Wielkiego co do możliwości utrzymania dotychczasowych zdobyczy.

G. Kucharczyk w wyważony sposób przedstawił politykę zagraniczną Prus w dobie krótkiego panowania Fryderyka Wilhelma II i następnie Fryderyka Wilhelma III, zwłaszcza zamienne plany ministra E.F. Hertzberga oraz próby zbrojnej konfrontacji z Austrią i ewentualnie z Rosją. Przy okazji poruszył kontrowersyjną w polskiej historiografii sprawę szukania przez antykrólewską opozycję w Rzeczypospolitej doby Sejmu Czteroletniego poparcia w Prusach i zawarcia z nimi sojuszu.Zdaniem Autora minister Hertzberg, popierając w Polsce antyrosyjską opozycję, początkowo chciał skłonić Rosję, toczącą wojnę z Turcją, do współdziałania z Prusami na terenie Rzeczypospolitej. Dopiero potem, w obliczu wojny z Austrią, sojusz z Polską miał przynieść Prusom konkretne korzyści. Wobec ustępstw ze

dyplomacji niemiecko-rosyjskiej w polityce mocarstw $w$ XVIII w., w: idem, Niemcy-Polska: $z$ dziejów trudnego dialogu historiograficznego, red. H. Olszewski, Poznań 2006, s.351-368. Trzeba pamiętać, że miało to miejsce faktycznie dopiero po 1772 r., czyli po pierwszym rozbiorze Polski. 
strony Austrii i wycofania się Anglii z antyrosyjskiej koalicji Prusy powróciły do swej polityki szukania porozumienia z Rosją kosztem państwa polsko-litewskiego. Dlatego też zdecydowały się na udział w drugim rozbiorze. G. Kucharczyk nie feruje tu wyroków na polskich polityków dążących do zbliżenia z Prusami. Z jego spokojnej relacji wynika, iż szanse powodzenia tej propruskiej polityki uzależnione były od ogólnej sytuacji panującej wówczas w Europie i nie można było ich z góry przekreślać. Inna rzecz, że Stanisław August był chyba lepszym strategiem niż jego opozycjoniści, gdyż od samego początku Sejmu Wielkiego podejrzewał (i słusznie) dyplomację pruską o prowadzenie podwójnej gry.

W następnej części swoich rozważań G. Kucharczyk przechodzi do wnikliwego przedstawienia polityki zagranicznej Prus w dobie rewolucji francuskiej (a także Napoleona). Relację tę przerywa tylko podrozdział dotyczący stosunku Prus do powstania kościuszkowskiego i ich udziału w trzecim rozbiorze Polski. Autor stwierdza przy tym, iż carowa Katarzyna II, niezadowolona ze zbyt skromnego zaangażowania Prus w wojnę z rewolucyjną Francją, nie zaakceptowała dalej idących terytorialnych żądań pruskich, wyraźnie faworyzując tym razem Austrię. Analizując politykę Prus w tym okresie, wskazuje, iż celem jej było nie tyle przeciwdziałanie tendencjom rewolucyjnym, ile szukanie nowych nabytków terytorialnych. Dlatego też początkowo Prusy gotowe były nawet współdziałać z Francją przeciw Austrii, ale wobec niepowodzenia tego planu zdecydowały się wspólnie z Austrią wystąpić przeciw Francji,licząc na zagarnięcie przy tej okazji księstewek położonych na lewym brzegu Renu. Brak sukcesów militarnych i zaangażowanie na wschodzie (tłumienie powstania kościuszkowskiego) sprawiły, że Prusy wycofały się z wojny z Francją w zamian za możliwość uzyskania nabytków na prawym brzegu Renu. Zresztą z pewną satysfakcją obserwowano wówczas w Berlinie klęski ponoszone wówczas przez Habsburgów. Prowadzona potem polityka neutralności przyniosła Prusom wcielenie do ich państwa kilku sekularyzowanych biskupstw i opactw (przyznanych im jako odszkodowanie za przejęte przez Francje niewielkie pruskie terytoria na lewym brzegu Renu). G. Kucharczyk, oceniając ówczesną postawę Prus, zwraca uwagę, że wobec zwiększającej się potęgi napoleońskiej Francji główny cel ich polityki - uzyskanie dominującej pozycji w Północnych Niemczech - nie mógł być zrealizowany, i to mimo zajęcia przez nie (za zgodą Napoleona) Hanoweru. Po francuskim zwycięstwie pod Austerlitz w 1805 r. Prusom groziło całkowite uzależnienie od Francji prowadzącej politykę faktów dokonanych. Co więcej, do Berlina docierały pogłoski, że w przyszłym układzie pokojowym walczące strony podzielą się terytorium neutralnych Prus. W tej sytuacji Fryderyk Wilhelm III zdecydował się stanąć po stronie antyfrancuskiej koalicji. Napoleon na pruskie ultimatum z września 1806 r. odpowiedział wkroczeniem wojsk do Prus, co skończyło się ich całkowitą klęską. G. Kucharczyk stwierdza, że pruska polityka neutralności mimo to miała swoje pozytywne strony, pozwoliła bowiem umocnić Prusom swą pozycję w Niemczech i uzyskać zdobycze terytorialne na ziemiach polskich, choć przyznaje, iż wcześniejsze wycofanie się z niej (jeszcze przed klęską Austrii i Rosji w 1805 r.) oznaczałoby przystąpienie do wojny w lepszej sytuacji pod względem wojskowym i politycznym. 
Autorstwa G. Kucharczyka jest także rozdział drugi, poświęcony przejawom kryzysu wewnętrznego państwa pruskiego po śmierci Fryderyka Wielkiego i początkom reform ustrojowych. Szczególną uwagę zwrócił Autor na poparcie udzielone przez nowego władcę Fryderyka Wilhelma II luterańskiej ortodoksji, zaostrzenie cenzury czy coraz wyraźniejszą nieufność przejawianą przez dwór wobec filozofii oświeceniowej, znajdującej wszak uprzednio pełną aprobatę w otoczeniu poprzedniego monarchy. Objęcie władzy przez Fryderyka Wilhelma III w 1797 r. wiąże natomiast z kształtowaniem się pruskiego „romantycznego” konserwatyzmu i pierwszymi dyskusjami nad koniecznością przeprowadzenia reform ustrojowych (zwłaszcza centralnej administracji) i społecznych (m.in. zniesienie poddaństwa chłopów), a także modernizacji armii, która zastygła w formach z czasów Fryderyka Wielkiego, a szukanie oszczędności doprowadziło do znacznego skrócenia czasu szkolenia żołnierzy. Osobne miejsce zajmuje w tym rozdziale szczegółowe omówienie wielkiej kodyfikacji prawa pruskiego z 1794 r. (Allgemeines Landrecht) - warto dodać, że wykorzystano tu pionierskie studia Stanisława Salmonowicza nad ówczesnymi kodyfikacjami powstałymi w państwach oświeconego absolutyzmu. Rozdział ten zamyka krótki szkic o specyfice ustrojowej ziem polskich zagarniętych przez Prusy w latach 1772-1795 oraz próbach ich integracji i unifikacji z pozostałymi terytoriami państwa pruskiego. Słusznie przy tym Autor wskazuje, że te aneksje przekształciły Prusy w państwo dwuwyznaniowe, protestancko-katolickie. Natomiast ocena wprowadzanych wówczas na tych terenach zmian społeczno-ustrojowych jest wyraźnie zbyt negatywna, miały one przecież także i swoje pozytywne strony.

Jak już wspomniałem, z ogólnej konstrukcji tej książki podzielonej chronologicznie na trzy okresy wyłamują się dwa rozdziały dotyczące spraw wyznaniowych oraz szeroko pojętej kultury i oświaty. W pierwszym z nich Z. Szultka zwraca uwagę na specyficzne cechy luteranizmu w Prusach, podporządkowanego państwu, a jednocześnie ulegającego wpływom pietyzmu cieszącego się poparciem Fryderyka Wilhelma I. Pietyzm dominował wśród duchowieństwa luterańskiego także w czasach Fryderyka Wielkiego, skądinąd deisty, kładącego zdecydowany nacisk na tolerancję religijną. Zdaniem Autora przyczyniło to się do kryzysu Kościoła ewangelicko-augsburskiego, gdyż pietyzm, dążąc początkowo do ożywienia luteranizmu i do rozwijania osobistej pobożności, stał się czynnikiem wychowywania społeczeństwa w duchu służby monarsze i państwu. Odrębne miejsce zajmują trzy podrozdziały dotyczące negatywnej polityki pruskich władców wobec Kościoła katolickiego. Kwestia ta stała się istotna po włączeniu do Prus prowincji z dominującą ludnością katolicką (Śląsk i ziemie zagarnięte w wyniku rozbiorów Polski). Nie wiem, czy było celowe umieszczenie tu podrozdziału o wyznaniowo-narodowościowych aspektach polityki Fryderyka Wielkiego wobec polskiej szlachty z Prus Zachodnich, gdyż sprawy te zostały już wystarczająco poruszone wcześniej. Omawiany rozdział zamyka krótkie omówienie mozaiki wyznaniowej mieszkańców państwa pruskiego. 
Kolejny rozdział poświęcono problematyce kultury umysłowej, materialnej i obyczajowej w osiemnastowiecznych Prusach. Autorem największej partii tekstu jest D. Łukasiewicz, jedynie podrozdział dotyczący ruchu wydawniczego i prasy napisał G. Kucharczyk, a architektury - A. Kamieński. We wprowadzeniu D. Łukasiewicz kładzie nacisk na rolę państwa pruskiego i jego potrzeb w rozwoju kultury. Następnie charakteryzuje pruski system oświatowy, doceniając wprowadzenie w 1763 r. powszechnego obowiązku szkolnego (dla dzieci do trzynastego lub czternastego roku życia), mimo że realizacja tego planu natrafiała na wiele trudności (m.in. finansowych), a poziom nauczania był początkowo bardzo niski. Niestety nie wyjaśnił (s. 794), czy tym obowiązkowym nauczaniem objęte były też dziewczęta. Wcześniej sygnalizował (s. 793), że część z nich (zwłaszcza w miastach) uczyła się w tzw. szkołach pokątnych (Winkelschulen). Sporo miejsca poświęca prowadzonym wówczas dyskusjom na temat reformy systemu oświatowego. Została ona w dużej mierze zrealizowana dopiero w początkach XIX w. przez ministra Juliusa Eberharda von Massowa. Pisząc o szkolnictwie na ziemiach polskich zagarniętych przez Prusy, D. Łukasiewicz zwraca uwagę na tendencje germanizacyjne, choć przyznaje, że wynikały one przede wszystkim z polityki unifikacji i konsolidowania dwunarodowego wówczas państwa. Reforma przyniosła jednak także i realne korzyści, gdyż na terenach przejętych w 1793 i 1795 r. utworzono 430 nowych szkół.

Interesująco przedstawiają się rozważania D. Łukasiewicza dotyczące ogólnego stanu kultury umysłowej (w tym nauki) w ówczesnych Prusach, gdzie grupą najbardziej chyba podatną na idee specyficznie pojmowanego oświecenia była warstwa biurokratyczno-urzędnicza, przy względnej słabości uniwersytetów (osobiście połączyłbym te uwagi z ostatnim podrozdziałem charakteryzującym główne linie rozwoju kultury pruskiej). Autor zwrócił przy tym uwage na znaczenie wśród uniwersyteckich dyscyplin kameralistyki i statystyki - jako nauk bezpośrednio przydatnych w administracji i zarządzaniu. Do wybitnych uczonych zaliczył Christiana Thomasiusa, Christiana Wolffa oraz Immanuela Kanta i szerzej przedstawił ich poglądy. Omawiając życie literackie, zaakcentował rozwój czasopiśmiennictwa (szerzej pisze o tym dalej G. Kucharczyk), a także powstawanie towarzystw literackich i salonów. Zasygnalizował też twórczość literatów związanych z Prusami (m.in. Johanna Gottfrieda Herdera, Ernesta Teodora Hoffmanna, Heinricha von Kleista), podkreślając, że najwybitniejsi twórcy niemieccy tworzyli jednak poza Prusami, gdyż tamtejsza cenzura uniemożliwiała zajmowanie się problematyką społeczno-polityczną. Spośród przedstawicieli sztuk plastycznych D. Łukasiewicz wyróżnia twórczość nadwornego malarza Hohenzollernów - paryżanina Antoine’a Pesne'a, rysownika i grafika - gdańszczanina Daniela Chodowieckiego oraz rzeźbiarzy - gdańszczanina Andreasa Schlütera i jedynego w tym gronie Prusaka Johanna Gottfrieda Schadowa. Stanowczo zbyt mało uwagi poświęcono muzyce, która cieszyła się w Prusach wielkim uznaniem, co nie dziwi, jeśli się pamięta o ulubionej przez Fryderyka Wielkiego grze na flecie i o tym, że sam król był utalentowanym kompozytorem (o czym zresztą nie wspomniano). 
Obszerny podrozdział poświęcony architekturze, napisany przez A. Kamieńskiego, przynosi wiele informacji o działalności czołowych architektów (A. Schlütera, Jean'a de Bodt, Georga Wenzeslausa von Knobelsdorffa, Karla Gottfrieda Langhausa i Davida Gilly), o najważniejszych obiektach powstałych wówczas (barokowy zamek królewski w Berlinie, rokokowy pałac w Sanssouci, klasycystyczna Brama Brandenburska), a także o licznych pałacach wzniesionych dla pruskiej arystokracji (zwłaszcza w Prusach Wschodnich dla Dönhoffów, Finckensteinów i Dohnów). Autor wskazuje na coraz większe znaczenie przypisywane planowaniu nowych układów przestrzennych miast. Wiele miejsca poświęca też budownictwu całego systemu potężnych twierdz (Koźle, Srebrna Góra, Kłodzko, Świdnica, Grudziądz), które miały zabezpieczyć zdobycze Fryderyka II.

Bardzo cenny (choć zbyt skrótowy) jest podrozdział pióra D. Łukasiewicza poświęcony warunkom życia codziennego.Zasługuje on na tym większą uwagę, iż problematyka ta na ogół nie wzbudza zainteresowania autorów syntez historycznych, a przecież dotyczy ona jednego z najważniejszych czynników jakości bytowania dawnego społeczeństwa. Autor wskazuje na znacznie niższy poziom życia we wschodnich i centralnych prowincjach państwa pruskiego niż w jego zachodnich enklawach. Przedstawia sposoby odżywiania się (ważną rolę w zapobieganiu klęskom głodu odegrało magazynowanie zapasów zboża i stopniowe wprowadzanie do uprawy ziemniaków), pojawienie się używek (tytoniu, kawy i herbaty), zwiększenie się spożycia wódki, a także reglamentowanie ubiorów odpowiednich dla poszczególnych stanów (przy okazji zakazywano importu kosztownych materiałów). Sporo uwagi poświęca też problematyce opieki medycznej i stanu zdrowotności. Na niewiele ponad dwóch stronach D. Łukasiewicz podjął próbę określenia głównych cech tworzącej się właśnie wtedy pruskiej mentalności, wskazując na „sakralizację” państwa, zmitologizowanie armii i jej sukcesów, hierarchiczność i autorytaryzm oraz na bezwzględne posłuszeństwo wobec władzy. Drugą stronę tej mentalności stanowiły jednak według Autora cechy pozytywne, a więc wykształcenie, profesjonalizm i oddanie wykonywanej pracy, co przejawiało się m.in. w znikomym występowaniu korupcji. W jakiejś mierze jest to akceptacja dotychczasowych stereotypów dotyczących tej pruskiej samoświadomości, ale rozważania te są przekonywające (choć na pewno zbyt skrótowe). Niejako aneksem do tego rozdziału jest syntetyczne omówienie stanu kultury polskiej na zagarniętych przez Prusy terenach Rzeczypospolitej.

W zakończeniu B. Wachowiak przedstawił główne linie rozwoju Prus w latach 1701-1806. Jest to obszerne podsumowanie (w jakiejś mierze streszczenie) głównych wątków omawianej tu syntezy. Trudno mi się jednak zgodzić ze stwierdzeniem (wyraźnie zresztą wykraczającym poza chronologiczne ramy tej książki), że włączenie w skład państwa pruskiego ziem polskich (po $1815 \mathrm{r}$. stanowiły one $23,5 \%$ powierzchni Prus) stało się przyczyną trudności z unifikacją tego organizmu państwowego w XIX w. i ,jednym z istotnych powodów ich [Prus] upadku" (s. 932). Warto pamiętać, że po 1848 r. głównym celem Prus było jednak zjednoczenie (czy raczej wchłonięcie) Niemiec, a dla utworzonej w 1871 r. Rzeszy Niemieckiej mającej aspiracje do przewodzenia w Europie, 
jeśli nie w świecie, problem mniejszości polskiej (podobnie zresztą jak nielicznej duńskiej) był raczej drugorzędny. Bardzo dobrze się stało, że końcowe rozważania B. Wachowiaka zostały w całości przetłumaczone na język niemiecki i zamykają tę książkę. Opublikowanie pierwotnej polskiej wersji tego zakończenia było natomiast, moim zdaniem, zbędne.

Całość pracy robi bardzo dobre wrażenie, jest ona napisana przystępnym językiem (nawet rozdziały poświęcone gospodarce dają się bez trudności czytać), przynosi wiele interesujących informacji, a do tego Autorzy zachowują wyraźny obiektywizm (co z wielu powodów nie zawsze było respektowane w polskiej historiografii), nie stroniąc bynajmniej od własnych ocen. Jedynie nieliczne fakty wymagałyby dodatkowych wyjaśnień, np. gdzie i kiedy Fryderyk I wzniósł kompleks pałacowy, który stał się siedzibą dworu. Ponieważ wcześniej była mowa o jego koronacji w Królewcu, nie jest jasne, czy pałac ten został zbudowany w tymże mieście, w Berlinie, a może w Poczdamie (s. 66). Odczuwa się w odpowiednich miejscach poszczególnych rozdziałów brak dat objęcia władzy przez kolejnych monarchów: Fryderyka Wilhelma I, Fryderyka II i Fryderyka Wilhelma II. Czy można mówić, że w początkach panowania Fryderyka Wilhelma I (a więc w latach dwudziestych XVIII w.) Prusy Książęce (Brandenburskie) były jeszcze związane z Polską? (s. 95). W rozdziale Z. Szultki dotyczącym terytorium i ludności państwa pruskiego zbędne są szczegółowe informacje o przebiegu aneksji Śląska i Fryzji (s. 429-431), szerzej pisał o tym już A. Kamieński w rozdziale o ówczesnej polityce pruskiej (s. 235-254).

W trakcie lektury tej obszernej pracy nasuwają się refleksje dotyczące porównań losów, a także ustroju społecznego, gospodarczego i administracyjnego Prus i Rzeczypospolitej w XVIII w. W tym czasie struktura społeczna tych obu państw pod pewnymi względami była podobna. Dominującą pozycję zajmowała w nich bowiem szlachta. Wyraźnie podkreślają to Autorzy niniejszej syntezy w odniesieniu do Prus. Różnice dotyczą natomiast liczebności stanu szlacheckiego. W Rzeczypospolitej odsetek szlachty wynosił przypuszczalnie 5-6\% (na przeważającym obszarze najwyżej 2-3\%, wyjątkiem było jednak Mazowsze, Podlasie i Żmudź, gdzie było kilkanaście procent szlachty) ${ }^{3}$, podczas gdy w państwie pruskim szlachta stanowiła tylko 1\% ludności wiejskiej (obejmującej 70\% ogółu mieszkańców). Występowało tu zresztą duże zróżnicowanie terytorialne, od 0,5\% szlachty wśród ogółu ludności wiejskiej w Księstwie Magdeburg do 0,9\% w Marchii Brandenburskiej, 1,1\% w Prusach Brandenburskich (Książęcych) i 1,4\% w Nowej Marchii i na Pomorzu (Szczecińskim). W uzyskanych w wyniku pierwszego rozbioru Polski Prusach Zachodnich i Okręgu Nadnoteckim odsetek szlachty w stosunku do ogółu ludności wynosił jedynie 1,2\% (to też potwierdza tezę o znacznie niższym, niż to przyjmowała starsza historiografia

${ }^{3}$ E. Rostworowski, Ilu było w Rzeczypospolitej obywateli szlachty?, KH 94, 1988, 3, s. 3-39. 
i niektórzy współcześni publicyści, udziale szlachty w strukturze społecznej dawnej Rzeczypospolitej sięgającym rzekomo mitycznych 10\%).

Problemem jest informacja podana przez Z. Szultkę, w ślad za monografią Jana Wąsickiego ${ }^{4}$, o wysokim (sięgającym $35 \%$ ) odsetku szlachty na obszarach zagarniętych przez Prusy podczas trzeciego rozbioru Polski, tzw. Prusach Nowowschodnich, to jest Ziemi Dobrzyńskiej, Północnym Mazowszu, części Podlasia, województwa trockiego i Żmudzi (s. 732). Wąsicki opierał się przede wszystkim na publikacji pruskiego urzędnika regencji białostockiej Augusta Carla Holschego Geographie und Statistik von West- Süd- und Neuostpreussen (t. 1-2, Berlin 18001804). Z. Szultka nie zweryfikował tych danych, tymczasem J. Wąsicki uwzględniając, że w całych Prusach Nowowschodnich było około 29 tys. rodzin szlacheckich (ale bez szlachty gołoty), przyjął, iż każda z nich liczyła 6 osób, co dało mu w sumie 170-180 tys. szlachty. W świetle pruskich zestawień statystycznych (nie zawsze zresztą dokładnych) na tym terenie mieszkało około 26 tys. szlachciców mających jakąś własność ziemską (choćby niewielką) i nieco ponad 5 tys. szlachty gołoty (nieosiadłej). Nie wszyscy spośród nich (zwłaszcza dotyczy to szlachty zagrodowej i gołoty) byli w stanie założyć rodziny. Liczba synów szlacheckich wynosiła według tych statystyk około 36,7 tys. Liczba córek zapewne była podobna. Uwzględniając nawet nieco większą liczbę kobiet w tych rodzinach, całkowita liczba szlachty w tej prowincji nie powinna przekraczać 130-135 tys. osób. Stanowiłoby to co najwyżej $25 \%$ ogółu ludności, co i tak było zjawiskiem wyjątkowym w skali europejskiej.

Z. Szultka podkreśla, że w Prusach Fryderyka II nadal istniały bardzo wyraźne podziały stanowe. Szlachta, której głównym zadaniem było pełnienie funkcji oficerskich i urzędniczych, podobnie jak i w Rzeczypospolitej nie mogła trudnić się zajęciami miejskimi, a mieszczanie nie mogli posiadać dóbr ziemskich, gdyż mieli lokować swe kapitały w handlu i produkcji rzemieślniczo-przemysłowej. Oczywiście w praktyce było z tym różnie i wśród kadry oficerskiej oraz urzędników spotykamy spory odsetek osób pochodzenia mieszczańskiego, a w $1800 \mathrm{r}$. 10\% majątków ziemskich należało do osób spoza stanu szlacheckiego.

Na przeważającym obszarze państwa pruskiego (w Brandenburgii, na Pomorzu Szczecińskim, w Prusach Wschodnich i Zachodnich) nadal obowiązywała pańszczyzna, choć w nieco niższym wymiarze niż w Rzeczypospolitej.Jedynie w domenach królewskich (stanowiących wszak znaczną część dóbr ziemskich) stopniowo była ona zamieniana na czynsze. Znaczący wzrost cen na produkty rolne od lat siedemdziesiątych XVIII w. powodował, iż położenie ludności chłopskiej polepszyło się wówczas (zahamowało to $\mathrm{z}$ drugiej strony dążenia do strukturalnych reform ustroju wiejskiego w dobrach szlacheckich).

Istotne różnice między Prusami a Rzecząpospolitą występowały jednak w funkcjonowaniu i ustroju władz, tak szczebla ogólnopaństwowego, jak i lokalnego. Pruska biurokracja opierała się wprawdzie na szlachcie, ,,ale wyróżniała

${ }^{4} \mathrm{~J}$. Wąsicki, Ziemie polskie pod zaborem pruskim. Prusy Nowowschodnie (Neuostpreussen) 1795-1806, Poznań 1963, s. 47-50. 
się wyjątkowo wysokim (nawet w skali europejskiej) odsetkiem mieszczaństwa w administracji centralnej i prowincjonalnej oraz oficerów" (s. 88). Co więcej, każdy urzędnik cywilny i wojskowy podlegał corocznej ocenie i zawsze można było go odwołać lub przenieść na inne stanowisko. Do tego dochodziła „zasada sprawowania urzędów poza obszarem pochodzenia". Co prawda, ta znakomicie zorganizowana machina biurokratyczna nie zawsze funkcjonowała bez zarzutu, ale najczęściej wynikało to ze sprzecznych dyrektyw bądź sporów kompetencyjnych. W jakiejś mierze przyczyniał się do tego Fryderyk Wielki, próbując rządzić za pomocą samego gabinetu, bez odpowiednich uzgodnień z ministrami.

Zupełnie odmienna była sytuacja w Rzeczypospolitej, gdzie urzędnicy wszystkich szczebli sprawowali swe funkcje w zasadzie dożywotnio (chyba że awansowali na wyższe stanowisko), a ich odpowiedzialność, choćby przed sejmem, jak to było w przypadku podskarbich, była czysto iluzoryczna. W praktyce nie wykształciły się też struktury administracji lokalnej. Starostowie stali się wyłącznie tenutariuszami dóbr ziemskich stanowiących uposażenie ich urzędu, a samorząd sejmikowy, z nielicznymi wyjątkami, nie stworzył organów wykonawczych. O fatalnej opinii (wypowiadanej zresztą raczej prywatnie niż publicznie), jaką sami Polacy mieli o tych niższych urzędnikach i o sądownictwie, może świadczyć list biskupa kujawskiego Adama Stanisława Grabowskiego do kanclerza wielkiego koronnego Andrzeja Stanisława Załuskiego z 1739 r. W odpowiedzi na prośbę o nakłonienie jednego ze starostów grodowych do podjęcia kroków przeciw szlachcicowi oskarżonemu o napad na pruskiego kupca pisał, że jest to w praktyce niemożliwe, gdyż starosta może co najwyżej pozwać szlachcica przed swój sąd. Ten będzie się jednak odwoływał do trybunału, „gdzie prawa nie słuchają i sprawiedliwości nie masz. [- - ] Jednym słowem trzeba by inszych praw, ażeby starostowie dworowi [grodowi] ukrzywdzonym cudzoziemcom i sprawiedliwości dogodzić mogli, bo przy teraźniejszych tego nie potrafią"5. Podobnie było, gdy w 1733 r. władze pruskie zatrzymały w Królewcu radziwiłłowskie transporty produktów rolnych, albowiem tamtejsi kupcy udzielili pożyczek Sapiehom, zapisanych na hipotekę dóbr, które następnie przeszły w ręce Radziwiłłów. Komisarz radziwiłłowski, nie mogąc dojść do porozumienia z Sapiehami, którzy nie zamierzali spłacić długu, radził swej mocodawczyni księżnie Annie Radziwiłłowej, by skierowała sprawę bezpośrednio do sądu w Królewcu, gdyż „u nich sąd, sprawiedliwość i decyzja”. Warto przy okazji zwrócić uwagę na fakt (wymagający zresztą chyba głębszych badań) pewnej fascynacji postacią Fryderyka Wielkiego przejawianą przez wielu przedstawicieli osiemnastowiecznych polskich elit politycznych i umysłowych.

W absolutystycznych Prusach przysłowiowa była już polska anarchia, którą zresztą we własnym interesie podtrzymywały. Tymczasem w Polsce nawet najdalej idące projekty reform (choćby Stanisława Konarskiego) zmierzały jedynie do

${ }^{5}$ Cyt. za J. Dygdała, Adam Stanisław Grabowski (1698-1766). Biskup, polityk, mecenas, Olsztyn 1994, s. 145.

${ }^{6}$ Idem, Radziwiłłowskie kłopoty ze spławem do Gdańska i Królewca w 1733 roku, ZH 77, 2012, 3, s. 14 . 
usunięcia ewidentnych nadużyć i do zbudowania dobrze funkcjonującej republikańskiej formy rządu, na czele z sejmem podejmującym decyzje większością głosów. Ewenementem była opinia wojewody kaliskiego Wojciecha Miaskowskiego, który odnosząc się do koncepcji Konarskiego, za jedyny skuteczny sposób dochodzenia sejmów uważał "stryczek na szyi mówców sejmowych"7, czy znacznie późniejsza publicystyka Józefa Pawlikowskiego pisana w duchu antyszlacheckim i prokrólewskim ${ }^{8}$. Zresztą badania nad polską myślą polityczną i ideologią doby staropolskiej koncentrują się na problematyce wolności ${ }^{9}$. Wydaje się jednak, że interesujące mogłyby być także poszukiwania wątków regalistycznych (a może nawet proabsolutystycznych), choć oczywiście chyba żaden z polskich ideologów i autorów pism politycznych nie występował otwarcie z takimi poglądami, konieczna byłaby tu analiza poufnej korespondencji, intymnych dzienników, może sylw.

Oceniając różnice w finansowych możliwościach obu państw, trzeba pamiętać, że znaczące dochody (39\%) przynosiły państwu pruskiemu domeny królewskie (obejmujące ponad 25\% użytków rolnych) - odpowiednik starostw i ekonomii w Rzeczypospolitej. W Prusach nastąpiło jednak wykluczenie szlachty od dzierżawienia domen, przejście od dzierżaw dożywotnich do sześcioletnich, powiększanie obszaru domen przez wykup zadłużonych dóbr szlacheckich (próbowała stosować te metody w Polsce królowa Bona, co wywołało powszechne oburzenie) i melioracje. Stopniowo następowało też przechodzenie w domenach z pańszczyzny na czynsze. Tymczasem w państwie polsko-litewskim starostowie przejmowali zdecydowaną większość dochodów z królewszczyzn i trzymali je dożywotnio, z możliwością późniejszej cesji na rzecz współmałżonka lub dzieci.

Warto porównać budżety Prus i znacznie większej Rzeczypospolitej. Podczas całego panowania znanego z oszczędności (by nie powiedzieć skąpstwa) Fryderyka Wilhelma I dochody państwa wyraźnie przewyższały wydatki. Obejmując tron w 1740 r., Fryderyk II dysponował nadwyżką w wysokości 8,7 mln talarów (około 52,2 mln złp.). Z. Szultka, zastrzegając się, że uchwycenie całości dochodów i wydatków tego monarchy sprawia duże trudności, i opierając się na dotychczasowej literaturze, podaje, iż w 1740 r. dochód państwa sięgał 7 mln talarów (42 mln złp.), po wojnach śląskich zwiększył się do poziomu 10-11 mln talarów (60-66 mln złp.), po 1772 r. doszedł do 15,5 mln talarów (93 mln złp.), a u schyłku rządów Fryderyka II wynosił blisko $20 \mathrm{mln}$ talarów (120 mln złp.). Odpowiednio mniejsze były wydatki, w 1740 r. niewiele ponad $6 \mathrm{mln}$ talarów (36 mln złp.), w latach pięćdziesiątych 9-12,5 mln (54-75 mln złp.), po 1772 r. około 11-11,5 mln (66-69 mln złp.),

${ }^{7}$ H. Dymnicka-Wołoszyńska, Miaskowski Wojciech Maksymilian, PSB, t. 20, Wrocław-Warszawa-Kraków 1975, s. 550.

${ }^{8}$ E. Rostworowski, Myśli polityczne Józefa Pawlikowskiego, w: idem, Legendy i fakty XVIII w., Warszawa 1965, s. 226-264.

${ }_{9}$ Zob. najnowsze prace: A. Grześkowiak-Krwawicz, Regina libertas. Wolność w polskiej myśli politycznej XVIII wieku, Gdańsk 2006 i M. Wyszomirska, Między obrona wolności a naprawa państwa. Rzeczpospolita jako przedmiot polemik politycznych $w$ dobie panowania Augusta III (1734-1763), Warszawa 2010. 
wreszcie w 1786 r. 16,7 mln (99 mln złp.). Tymczasem w ustawie budżetowej przyjętej przez sejm Rzeczypospolitej w 1717 r. dochody i wydatki określono na poziomie 8,1 mln złp., przy czym w połowie XVIII w. przychody osiągnęły poziom 9,3 mln złp. Wyraźne zwiększenie się dochodów państwa nastąpiło dopiero w czasach Stanisława Augusta, sięgając w 1766 r. prawie $12 \mathrm{mln}$ złp. Po pierwszym rozbiorze wynosiły one 13,2 mln złp. rocznie, w latach osiemdziesiątych XVIII w. ustabilizowały się na poziomie $18,5 \mathrm{mln}$ złp., by dopiero w dobie Sejmu Wielkiego na krótki czas dojść do sumy 50 mln złp. w ciągu roku ${ }^{10}$. Porównanie budżetów obu państw dobitnie wskazuje na ogromne różnice w ich zasobach finansowych i wynikające stąd odmienne możliwości utrzymania odpowiednio licznej armii.

Na pewno nie było to zamiarem Autorów niniejszej syntezy dziejów osiemnastowiecznych Prus, ale czytelnikowi mającemu jakąś wiedzę historyczną mimowolnie nasuwa się wniosek o wyższości systemu absolutystycznego (zwłaszcza tzw. oświeconego absolutyzmu) nad panującym w Rzeczypospolitej dogmatem złotej, szlacheckiej wolności uniemożliwiającym prawidłowe funkcjonowanie państwa. Może też dojść do przekonania (słusznego zresztą) o lepszych warunkach życia w uporządkowanym państwie pruskim (choć pod stałą kontrolą biurokracji,nawet nie zawsze kompetentnej i podejmującej czasem błędne decyzje) niż w pozornie wolnej Rzeczypospolitej. Oczywiście można wskazać, że podobnie jak w końcu XVIII w. upadła Polska, także absolutystyczne państwo pruskie błyskawicznie uległo w 1806 r. wojskom napoleońskiej Francji. Była to jednak wojna z ogólnonarodową armią nowego typu. Natomiast po klęsce władze i społeczeństwo Prus były zdolne do podjęcia daleko idących reform społecznych i ustrojowych. Warto zauważyć, że w historiografii polskiej już tzw. szkoła krakowska w XIX w. dowodziła, że to brak silnej władzy królewskiej doprowadził do upadku państwa polsko-litewskiego. Także Antoni Mączak w swych ostatnich pracach coraz wyraźniej przychylał się do tezy, że to absolutyzm (czy może tylko tendencje absolutystyczne) stanowił regułę w rozwoju europejskiego państwa doby nowożytnej, zapewniał jego centralizację, równowagę (do czasu) między stanami i wreszcie dawał państwu niezbędną siłę militarną. Do Rzeczypospolitej natomiast odnosiły się słowa tego znakomitego historyka: „Biada temu państwu, które wśród potężnych monarchów nie postawiło na centralizację, które w swym ustroju i kulturze dało prymat peryferiom"11. Podobne stanowisko zajmuje ostatnio w swej inspirującej pracy z pogranicza historii i psychohistorii Jan Sowa, zwracając uwagę na iluzoryczność istnienia struktur państwowych dawnej Rzeczypospolitej ${ }^{12}$.

${ }^{10}$ M. Drozdowski, Działalność budżetowa sejmu Rzeczypospolitej w czasach saskich, RDSG 38, 1977, s. 130-136; idem, Podstawy finansowe działalności państwowej w Polsce 1764-1793, Warszawa-Poznań 1975, s. 34-35, 80, 117-118, 153-154, 157-158.

${ }^{11}$ A. Mączak, Rządzący i rządzeni. Władza i społeczeństwo w Europie wczesnonowożytnej, Warszawa 2002, s.117-128, cytat ze s. 122.

12 J. Sowa, Fantomowe ciało króla. Peryferyjne zmagania z nowoczesną forma, Kraków 2011. 
Można zrozumieć, że niektórzy współcześni historycy niemieccy z wielu przyczyn negatywnie oceniają pruski osiemnastowieczny absolutyzm i widzą głównie jego negatywne strony. Mają tu zresztą znakomitego poprzednika,jednego z twórców niemieckiej socjaldemokracji Franza Mehringa, który w swojej publicystycznej w gruncie rzeczy pracy Legenda o Lessingu (Die Lessing-Legende, Stuttgart 1893) zdecydowanie potępił system rządów Fryderyka Wielkiego, gdyż według niego sprawowane one były wyłącznie w interesie stanu szlacheckiego i nie przyniosły niczego dobrego warstwom niższym, chłopstwu i mieszczaństwu. Dobrze się stało, że Autorzy poznańskiej syntezy nie poszli tym śladem i zachowali wyraźny obiektywizm w ocenie państwa i społeczeństwa osiemnastowiecznych Prus, dostrzegając ewidentne wady, ale też i zalety tego systemu.

Książka jest starannie wydana (choć przydałaby się uważniejsza korekta, $n p . w$ indeksie znany minister Hertzberg jest zapisany jako Herzberg), zaopatrzona w bogaty materiał ilustracyjny, liczne tabele statystyczne, tablice genealogiczne czterech linii dynastii Hohenzollernów, mapy oraz indeksy - osobowy (opracowany przez Michała Zwierzykowskiego) i geograficzny (sporządzony przez Marka Daroszewskiego). Nie ulega wątpliwości, że recenzowana praca stanowi znaczące osiągnięcie naukowe poznańskiego środowiska historycznego.

\section{The History of Frederician Prussia in the Eighteenth Century, or on the Supremacy of Absolutism over Gentry Liberty}

The copious and detailed book: Prusy w okresie monarchii absolutnej (1701-1806), ed. Bogdan Wachowiak, Poznań 2010 (series: Historia Prus. Narodziny - mocarstwowość - obumieranie, vol. 2) is the work of five authors. Almost half of the text was written by Zygmunt Szultka (i.e. chapters on economic, social and systemic relations), and the author of one-quarter of the publication is Andrzej Kamieński, who discussed Prussian foreign policy in 1701-1786 and the development of architecture. Dariusz Łukasiewicz focused on widely comprehended culture and the conditions of daily life, while Grzegorz Kucharczyk considered foreign policy, symptoms of the domestic crisis during the reign of Frederick William II and Frederick William III, and the eighteenth-century publication movement.

The book's characteristic feature is the extremely thorough use of the existing literature on the subject, predominantly German but also English-language, French and Polish. Upon numerous occasions, the authors (in particular Z. Szultka) conducted additional archival surveys; hence the book is not so much a synthesis as a compendium of knowledge about the Prussian state. The overall impression is excellent, the publication is written lucidly (this holds true even for chapters about the economy) and provides a plethora of interesting information, with the authors remaining distinctly objective but without shying from personal opinions.

The presented study inclines towards a comparison of the fate and the social, economic and administrative systems of eighteenth-century Prussia and the Commonwealth. The readers draw the obvious conclusion about the supremacy of the absolutist system (especially so-called enlightened absolutism) over the ideology of the golden liberty of the gentry prevalent in the Commonwealth and the suitable 
functioning of the state. Furthermore, they may arrive at the correct conviction about better living conditions in the orderly Prussian state (albeit under the constant control of the bureaucracy) than in the ostensibly free Commonwealth. In Polish historiography already the so-called Cracow school (second half of the nineteenth century) argued that the absence of strong royal authority resulted in the fall of the Polish-Lithuanian state.

Translated by Aleksandra Rodzińska-Chojnowska 